\title{
Balkan fra substantiv til verbum - og tilbage igen
}

\section{Slavenka Drakulic}

Vesteuropæerne vil ikke forstå blodighederne på Balkan. De har barrikaderet sig i den opfattelse, at Balkan er alt det, som Europa ikke er, mener den kroatiske forfatterinde

Jeg må indrømme, at jeg ikke kan lide navnet Balkan. Du kan med rette spørge hvorfor? Er navne ikke neutrale og på en måde også uskyldige, for det afhænger jo alt sammen af, hvordan vi bruger dem og i hvilken sammenhæng? Eller er navnet Balkan mere en slags supermarked, hvor folk kan gå rundt og fylde indkøbskurven med meninger, som allerede står på hylderne? Hvorfor har jeg så stærke følelser omkring dette særlige navn? Når alt kommer til alt, er navnet på et geografisk område ikke en person, som man kan lide eller ikke.

Men jeg må sige, at jeg har god grund til den antipati. Jeg har været vidne til navnets transformering til verbet 'at balkanisere' og har som mange andre lidt under den metamorfose. Jeg vil ikke her diskutere, hvordan vi kunne have forhindret det $i$ at ske, det ville bare være en jammerklage post-festum. Jeg vil hellere se på, hvordan verbet bare kunne blive et substantiv igen.

Vi har alle hørt og læst om balkaniseringen af Sovjetunionen. Jeg ser også ofte overskrifter i aviser som 'Balkaniseringen af Kenya' eller 'Washington promoverer Bolivias balkanisering'.

For nylig læste jeg Ryszard Kapuscinskis bog om Afrika The Shadow of the Sun, hvor jeg faldt over denne sætning: "Afrikaneren er velbevandret i geografien for venskab og had mellem stammer, som ikke er mindre kritiske fænomener end dem på Balkan i dag".

Hvis du går videre til Google, vil du finde ikke mindre end 277.000 indgange til balkanisering, og Wikipedia vil forklare dig, at balkanisering er en geopolitisk term, der op- 
rindelig blev brugt til at beskrive processer for fragmentering eller opdeling af en region eller stat i mindre regioner og stater, som er fjendtlige eller i hvert fald ikke samarbejdsvillige over for hinanden.

Begrebet opstod af det 20. århundredes Balkan. Den første balkanisering lå i Balkankrigene, og begrebet blev genbekræftet af krigene i det tidligere Jugoslavien i 1990'erne. Begrebet bruges også til at beskrive andre former for disintegration, som da Gordon Brown i januar 2007 talte om 'balkanisering af Storbritannien' i forbindelse med opsving i støtte til Skotlands uafhængighed.

Definitionen i Merriam-Webster Dictionary tilføjer, at balkanisering er et transitivt verbum, som betyder 'at dele' eller 'sætte i forskellige båse'.

Det er unødvendigt at sige, at det er et berygtet ord. Det er ikke kun et navn længere. Det er ikke uskyldigt.

\section{Supermarkedet som metafor}

For at gå tilbage til min metafor 'supermarked' afhænger det, som du finder til indkøbskurven, selvfølgelig af, hvor du køber ind. Hvis du gør dine indkøb i Wien eller et andet sted i 'Vesten' eller 'Europe' (og der er andre supermarkeder, som er fyldt til bristepunktet med betydninger!) er din forståelse groft sagt, at Balkan er, hvad Europa ikke er. Blæs på geografi, for grænsen er et sted i bevidstheden snarere end i selve landskabet. Hos nutidens menne- sker er det sandsynligvis i deres erindringer i form af tv-billeder fra de nylige krige. Hvis du lukker dine øjne og siger Balkan, vil det sikkert være billeder af flygtninge, grædende kvinder med tørklæder, ruinerne i Vukovar, døde kroppe, flere døde kroppe eller Christianne Amanpour, der rapporterer for $\mathrm{CNN}$ fra et sted af tragedie og ødelæggelse.

Så husker du måske tallene (over 7.000 muslimske mænd henrettet $\mathrm{i}$ Srebrenica, 60.000 kvinder voldtaget, 200.000 døde i Bosnien, 10.000 sårede børn og så videre). Eller hvis du ikke husker tal, vil du nok stadig huske ansigter, især det af en skeletlignende ung mand bag pigtråd omkring en serbisk koncentrationslejr i Omarska, Bosnien. Eller ansigter af krigsforbrydere som Ratko Mladic, en Radoslav Karadzic med paryk eller Slobodan Milosevic.

Det, som jeg tænker på er i stedet en pullover, en hvid håndstrikket pullover med røde plamager. Den tilhører faderen til en lille pige, der blev dræbt af granatsplinter. Da faderen holdt hendes lille krop, gennemvædede hendes blod den pullover, som han stadig bar kort efter, da CNN filmede ham.

Hvem kan bebrejde en person at huske alt det, når vedkommende hører navnet Balkan? Nogle af jer vil sikkert også huske Adriaterhavets usædvanlige blå farve, den gode mad eller stranden med hvide småsten, den strand, som du besøgte med dine forældre tilbage til 1960'- 
erne, da alt var anderledes. Men jeg er bange for, at ideen om Balkan som ikke-Europa allerede er blevet stærkt genetableret i den kollektive bevidsthed, siden du sidst besøgte det idylliske sted.

Maria Todorovas bog Imagining The Balkans har gjort folk endnu mere bevidste om den 'imaginary geography', som vi har med at gøre her, for nu at bruge Edward Saids udtryk i Orientalism. Todorova påpeger, at Balkan er et gammelt navn (det tyrkiske navn for Stara Planina bjerget i Bulgarien) men et ret nyt begreb fra slutningen af det 19 . århundrede. Så med en slags 'litterær kolonisering' blev Balkan langsomt til et mørkt og farligt, men også eksotisk sted.

Det skete takket være forskellige vestlige skribenter, fra Bram Stoker og Karl May til Rebecca West og Agatha Christie. Og jeg kan tilføje, at det gik hele vejen til efterkrigserindringerne hos politikere som David Owen eller Richard Holbrooke, eller guidebøgerne af Robert Kaplan og Peter Handke. Balkan blev et rum, hvor mytologien styrer historien, og indbyggerne er vilde og eksotiske mennesker, for hvem blod og tilhørsforhold er de vigtigste værdier, hvor konflikter og religiøse krige lurer overalt i dette usikkerhedens rum.

Som en konsekvens blev indbyggerne i det rum-navn-verbum-imagesymbolske-landskab selv gidsler for denne negative overtone. De (vi) kan ikke lide at høre til der, og derfor søger vi at komme væk fra stedet, som vi ikke vil forbindes med.

\section{Balkan er de andre}

Hvis man anskuer det med en insiders syn på Balkan, ser det anderledes ud: "Balkan - det er de andre!", som den slovenske sociolog, Rastko Moènik, udtrykte det i sin åbenhjertige parafrase. Og følgelig ser vi hver især, slovenere, kroater, serbere og så videre, længere østpå efter Balkan, som denne symbolsk/imaginære grænse flytter fra Wien til Trieste og Ljubljana, så til Zagreb og Sarajevo og videre til Beograd og selv mere sydøst til Pristina. Der er ingen grænse i verden, som er så fleksibel, netop fordi det ikke så meget er en grænse som en opfattelse.

Todorovas analyse af historien om negative billeder af Balkan er meget interessant. (Bemærk at hun nævner mig, som en af de forfattere, der udnytter det negative billede ved at bruge det som et transitivt verbum i stedet for som substantiv i min bog Balkan Express. Og jeg indrømmer, at det gjorde jeg).

Men jeg husker imidlertid selv, hvordan den ændring skete i løbet af det sidste årti, men som vi allerede hørte, startede transformationen af navnet ikke i 1991. Den startede med Balkankrigene og med Gavrilo Princips mord på Franz Ferdinand. Og en generation senere med Anden Verdenskrig fulgt af Jugoslavi- 
ens sammenbrud. Dengang i Jugoslavien blev udtrykket Balkan ikke brugt så meget. Og når det skete, var det ikke udelukkende på negativ vis. Det var brugt til at definere en persons primitive adfærd, som når en mand slår sin kone.

Den kroatiske forfatter Miroslav Krležas berømte udtryk for politik som 'balkanska krèma', en balkansk pub, hvor slagsmål starter, så snart lyset slukkes - var den anden måde, vi brugte det. Men for unge mennesker var der også Johnny Štuliaes populære sang 'Balkane moj' (Mit Balkan) fra midten af 1980'erne, som ikke omfattede nogen af de 'gamle' nedsættende betydninger.

Men vi kan ikke afvise hele den negative forestilling, fordi den ikke kun er fri fantasi. De seneste krige genbekræftede dette mentale landskab som et rædslernes og splittelsernes sted. Desuden er nye grænser trukket, som i sandhed ikke kun er symbolske, men også virkelige, malet med blodets klare røde farve.

Hele Balkans historie som subjektet, der blev til verbum, er endog mere pinefuld for mig som forfatter, fordi 'krigen på ord' gik forud for krigen på slagmarken.

Jeg var vidne til, hvor skadelige ord kan være. Ingen krig sker bare; der skal propaganda og langvarige psykologiske forberedelser til, før myrderierne kan starte. Det er sædvanligvis personer i kultur, uddannelse eller medier som forfattere, lærere, kunstnere og selvfølgelig journalister, som gives den opgave af regimer.

Hver gang jeg giver en forelæsning eller et foredrag i Vesten, får jeg spørgsmålet: hvordan og hvorfor startede krigen i Jugoslavien? Det sker, selv om der er gået så mange år og skrevet så mange avisartikler, lavet så mange tv-programmer og udgivet så mange bøger, måske tusinder.

Ja i sandhed, hvorfor faldt dette rige land, som var befriet for sovjetlignende kommunisme og uden for Moskvas rækkevidde sammen i en sådan blodig og brutal krig? Mit foretrukne og meget lakoniske svar er: vores land brød sammen på grund af italienske sko! Fordi vi kunne rejse til udlandet og fra tid til anden købe det, som vi ikke kunne få hjemme, troede vi, at vi var frie. Vi bekymrede os ikke om at udvikle nogen form for demokratisk politisk alternativ, og det vakuum, som opstod efter kommunismens sammenbrud, blev senere fyldt med nationalisme.

\section{Unges kendskab til Balkan}

I de fjorten år siden krigenes afslutning voksede en hel generation op både på Balkan og i Vesten. Hvad ved de i dag? Hvad andet end klicheerne kender den unge generation i Vesten? Her har jeg problemer med vesteuropæere, for efter så mange år går jeg ud fra, at folk i Vesten ikke ønsker at forstå, hvordan det skete. Det er for kompliceret, si- 
ger de som regel. Først troede jeg, at det bare var dovenskab, som forhindrede dem i endelig at lære nogle få historiske facts. Men jeg ændrede opfattelse efter at være stillet det samme spørgsmål, igen og igen. $\mathrm{Nu}$ tror jeg, at de forfærdelige tv-billeder fra krigene er en meget effektiv undskyldning for ikke at forstå. Folk som os, der kommer derfra, og vores krige kan slet ikke forstås, simpelthen fordi vi er så anderledes. Disse billeder og erindringer fungerer som et skjold.

Hvis europæerne ville sige, at de forstår de frygtindgydende begivenheder, ville det betyde, at vi alle er af samme slags eller i det mindste ligner hinanden. Men det er mere sikkert at afvise den mulighed og holde en nødvendig og såkaldt sund afstand fra sådanne naboer (husk at Balkan er det, som Europa ikke er).

Som om Vesten var et helligt territorium, ubesmittet af det ondes hånd. Som om europæiske nationalstater og revolutioner ikke var skabt i blod, som om Auschwitz ikke fandt sted. Intet blod der, ingen knive, ingen slagterier, ingen synlig brutalitet. Billeder af udsultede døde kroppe? De er måske ikke glemt, blot skubbet længere tilbage i erindringen. Der måtte jo levnes plads til de seneste rædsler i Bagdad eller Abu Ghraib.

Når alt kommer til alt er der grænser for, hvor meget man kan tage. Der må være en horror-kvote, et punkt hvorefter vold ikke længere betyder noget. Det får mig til at tænke over, hvor lang tid det tog tyskerne at slippe af med det billede af at være folkemordere, der adlyder enhver ordre. Det skabte i en lang periode forestillingen om den tyske karakter hos os, herunder mig selv. Sådan et historisk perspektiv giver mig håb. Der er ikke gået så mange år endda siden krigens afslutning på Balkan. Vel?

\section{Kan navnet vaskes rent?}

På den anden side. Hvis der er gået næsten ni årtier med at koge navnet Balkan ned til et verbum, hvor lang tid vil der så gå med at ændre det tilbage? Kan det navn blive renset og poleret? Kan vi få det til at skinne igen som et personligt navn? Hvordan gør vi det?

Jeg tror, at vi først - og her mener jeg os fra det tidligere Jugoslavien skal indrømme, at vi selv bidrog til genoplivelse af 'balkanisering', fordi verbet at 'balkanisere' blev genrejst med vores hjælp. Det var os og ikke udlændinge, der udkæmpede krigene med hinanden. At indrømme det er en begyndelse på ændringen, rengøringen og pudsningen. Det gør man med ord og billeder, med kultur, kunst og medier på præcis samme måde, som de negative billeder blev skabt.

I transformationsprocessen af kommunistiske lande til demokratier blev kunst og kultur klart tabere. Mens der bliver stadig færre statslige 
midler, er der heller ikke noget system af private sponsorer. Store private lokale firmaer investerer hellere i sport! Og det værste er, at offentlighedens interesse i kultur og kunst også er svækket. Kampen for overlevelse under cowboy-kapitalismen levner ingen tid, energi eller penge til kultur.

Den gennemsnitlige månedsløn i Balkans tidligere kommunistiske lande er nogle få hundrede euro (200-700). Samtidig er prisen på en bog lige så høj som i Vesten, hvis ikke endnu højere.

På massemediernes område oplever vi stærk konkurrence mellem offentlige og kommercielle interesser. Aviser gøres til pengemaskiner, så det offentlige rum skrumper ind, og pladsen til kultur forsvinder. Der er ingen penge i kultur, med mindre den er villig til at optræde som propaganda. Det kaldes ikke længere politisk propaganda, men annoncering.

\section{Frihed uden penge}

Hidtil har vi på det kulturelle område fået frihed af den nye politiske og økonomiske orden. Men hvad skal man stille op med friheden uden penge?

Det er klart, at kulturen marginaliseres, når den kun udsættes for markedskræfterne. Men kultur er for vigtig til kun at blive udsat for markedet. Det vigtige ved kultur og kunst er, at de repræsentere kapital, eller sagt på en anden måde, kultur producerer 'symbolsk kapital', som har magt til social inddragelse og spredning af værdier. Med kultur mener jeg her produktionen af performances, videoer, bøger, udstillinger, film, musik og teater.

Det paradoksale ved kunst og kultur er, at mens relativt få penge investeres i det, er det stadig den bedste eksportartikel, som kan betyde meget for et land eller en region i en bredere offentlighed. Det skaber også en vis balance, for selv et lille land kan her yde meget. Det var for eksempel tilfældet, da Zagreb Filharmoniske Orkester for ikke så længe siden havde en koncert i Wien. Franz Morak, østrigsk skuespiller og politiker, sagde: "Dette er den største succes for kroatisk udenrigspolitik i de sidste ti år".

Ved at præsentere eller indoptage et land gennem kultur og kunst, får du et anderledes og differentieret billede, der underminerer det image, der som regel reducerer lande til en region med en fællesnævner. Men den største fordel er, at alle kan vinde gennem en sådan præsentation af kunst og kultur.

Det givne land kan vinde. Små lande, der frygter for deres nationale identitet, kan gennem kunst og kultur bekræfte den identitet på en større scene. Det modarbejder frygten for at gå tabt i EU og frygten for globaliseringen. Kunst og kultur er, om man vil, praktiske redskaber til at opnå positive effekter på både 
ydre og indre planer. Det er den billigste og hurtigste vej til Europa. Jeg tror, at vi på Balkan må stille os selv et andet vigtigst spørgsmål: Hvad kan vi bidrage med til EU, til vores alles fremtidige hjem?

Når vi stilles sådan et spørgsmål, er vi stille en tid, lidt forlegne, fordi vi ikke har stillet os selv det spørgsmål! Men vi kommer hurtigt (improvisering anses for at være en af vores stærke sider!) med et 'vittigt' svar: at overleve!. Vi vil lære jer at overleve på trods af alt! Vi tænker ikke rigtig over, at for jer må det lyde overfladisk. Men det kan vi ikke rigtig indrømme over for os selv.

Vores liv under kommunisme handlede kun om overlevelse, så at indse at ingen virkelige har brug for den viden nu, får os til at føle os som en endnu større byrde. Vores liv vil på en måde virke forspildt.

Det synes oplagt for mig, at der er to ting, som vi kan bidrage med: på den ene side kunst og kultur og på den anden side en ung, uddannet befolkning med vid, intelligens og nysgerrighed.

Uden kultur vil økonomi og politik ikke virke på langt sigt. EU har behov for et klister, som kun kan komme fra andre sfærer, som alle lande, hvor små og kontroversielle, de end måtte være, også kan bidrage til. Det er ikke så åbenlyst - men synligt på mere end en måde - at folk stadig tænker på andet end penge. I det mindste i Europa.

Så for at runde af: Hvis Balkan virkelig vender tilbage til Europa, skal det være i form af et substantiv og ikke er verbum.

Slavenka Drakulic er kroatisk forfatterinde.

Oversat fra engelsk af Vibeke Sperling. 